\title{
PUBLIC POLICIES AND STRATEGIES OF A COMPLEX SYSTEM: THE CHANGE IN THE URBAN MOBILITY SYSTEM OF BOGOTÁ
}

POLÍTICAS PÚBLICAS E ESTRATÉGIAS DE UM SISTEMA COMPLEXO: A MUDANCCA NO SISTEMA DE MOBILIDADE URBANA DE BOGOTÁ

\author{
Bernardo Meyer ${ }^{1}$ \\ Victor Meyer Junior²
}

1 Universidade Federal de Santa Catarina, Florianópolis, Santa Catarina, Brazil.

2 Pontifícia Universidade Católica do Paraná (PUCPR). Curitiba, Paraná, Brazil,

\begin{abstract}
Purpose - Urban mobility is one of the most relevant themes in discussions regarding quality of life in large urban centers worldwide. It is a challenge that local governments have been facing due to a significant growth in the urban population. The purpose of this study is to analyze the changes in public transport made by the local government in the city of Bogotá, Colombia

Design/methodology/approach - It is an in-depth case study of a qualitative nature, based upon primary (interviews and observation) and secondary data. Data was collected in Brazil and Colômbia.

Findings - The case signaled a significant change process by improving urban mobility through the implementation of successful public policies and strategies. The findings indicated that transforming a chaotic public transport system into a point of reference in this field is a notable effort.

Practical implications - This study provides insights to public administrators that manage organizations that operate complex systems and pluralistic contexts

Originality/value - This paper contributes to the field by discussing a unique case study in which the administration of a large capital of a South American country promoted a substantial change in the urban mobility system, tackling obstacles and developing an efficient approach.
\end{abstract}

Keywords - Public Transport, Public Administration, Local Government, Strategy 


\section{RESUMO}

Objetivo - Mobilidade urbana é um dos temas mais comuns em discussões que tratem de qualidade de vida em grandes cidades em todo o mundo. Trata-se de desafio que governos locais tem enfrentado em face ao processo de urbanização. O objetivo deste estudo é analisar a experiência de Bogotá, Colômbia, na mudança de sistema de transporte público.

Design/Metodologia/Abordagem - Essa pesquisa caracteriza-se por ser um estudo de caso em profundidade de natureza qualitativa, baseado em dados primários (entrevistas e observação) e secundários coletados. Os dados foram coletados tanto no Brasil como na Colômbia.

Resultados - $O$ estudo mostra um processo de mudança significativo na mobilidade urbana por meio da implementação de políticas públicas e estratégias. Os resultados indicaram que transformar um sistema de transporte público caótico em um exemplo para o mundo é um esforço notável.

Implicações práticas - Esse estudo proporciona insights aos administradores públicos que gerenciam organizações que operam sistemas complexos e contextos pluralísticos.

Originalidade/Valor - A contribuição deste trabalho concentra-se na discussão de um caso único em que a administração de uma grande capital sul-americana promoveu mudança substantiva no sistema de mobilidade urbana, ao vencer obstáculos e implantar uma eficiente abordagem.

Palavras-Chave - Transporte Público, Administração Pública, Governo Local, Estratégia

\section{INTRODUCTION}

Urban mobility is one of the most popular themes in discussions regarding the challenges facing big cities worldwide. Almost every large city in the world confronts many problems related to this theme due to its direct relationship with the quality of life. As urban concentrations increase all over the world and the overall consuming power of the population grows, on a global scale, masses of people move around every day from one place to other, using cars, buses, boats, trains, subways, and motorcycles (Acharya, 2005).

All this commuting leads to traffic jams and intensifies the danger of crashes, contributing to the complexity of public transport in urban centers. Consequently, local governments have analyzed alternatives and sought to implement strategies in order to improve this situation. In this context, some governments have developed creative solutions that are well adapted to their specific realities.

Local governments have been especially innovative in using strategies to improve the quality of life of their inhabitants (Barber, 2013). Cities, such as Chicago, Sidney and London, have been described as examples of municipalities that succeeded in developing and adjusting adequate strategies to face urban mobility problems and improve urban mobility conditions. Today, a modern urban mobility concept involves not only transportation and infrastructure developments, but also a sustainable and very friendly environmental approach, contributing to more integration among people who live in urban areas.

Problems of urban mobility also have an economic component, as they mean higher transportation costs to society. Companies spend more resources on transporting their goods and people waste their time and money in traffic jams every day. In the end, urban mobility problems are costly for everyone.

The purpose of this work is to analyze the change that was made in the public transport system by the local government in the city of Bogotá. It signaled a significant modification in the public transportation system in the metropolitan area of the city. The relevant outcomes of this change in urban mobility were recognized not only locally and nationally, but also internationally, revealing a successful public endeavor and case. One of the main reasons that make the study of the case of Bogotá so unique is the fact that the city underwent an extensive transformation process, from a city with one of the most chaotic urban mobility systems in the world to an effective and internationally recognized model (Montezuma, 2005). 
This paper focuses on the role played by the city administration, the closest to the population, and consequently, to the needs and demands of citizens. A significant effort was made by the city administration to study, strategize and change the public transportation system of Bogotá, between 1997 and 2000. This effort led to a more agile and creative response by the local government in developing solutions to the problems facing the community.

The local government also took charge of implementing public policies designed not only at the city level, but also regionally, since it connected the nation's capital to its surrounding cities. We sought to answer the following research question: How was the change in the public transport system was achieved by the city administration?

Cities are understood as complex systems, in accordance with Cilliers (1998) and Stacey (2011). In addition, public policy was used as public decisions (Dye, 2017) to improve a chaotic public transportation system in Bogota.

Two major components constitute the strong points of this paper. The first is its analysis of critical elements mobilized by the city administration to promote the change process. This was a decision made by the local government that required political and social skills to overcome barriers that emerged during the process. The second is an examination of the critical strategies enacted by public agents to reify the public policy used to respond to specific social, political, and economic obstacles to promote change and create a more effective transportation system.

This paper contributes to the field by discussing a unique case study in which the administration of a large capital of a South American country promoted a substantial change in the urban mobility system, tackling obstacles and developing a modern and efficient approach that led to clear improvements in the quality of services delivered to the population. The case of the transformation of Bogota's public transportation system is a result of strategic decisions and actions that resulted in a successful, internationally recognized endeavor (Cervero et al, 2017).

The article's theoretical contribution is fourfold: first, the courage to tackle a complex political problem; second, the strategy combined two important factors for developing countries, namely lower cost of implementation and high passenger capacity; third, it resulted in greater operational efficiency; and fourth, the integration of concepts that are important to any city nowadays, namely quality of life, sustainability, and humanization.

\section{THEORETICAL BACKGROUND}

While public policy states the purpose, priorities and guidelines for public administration to perform (Dye, 2017), complexity theory reveals a context in which a local government operates through a variety of agents who combine public policies, processes, and a dynamic environment within an intricate network of interactions (Anderson \& Meyer, 2017). Strategy encompasses decisions and actions by public officials to turn public policy into a reality. Thus, to manage such a complex system constitutes a challenge for public administrators (Bovaird, 2008).

In this context, a plurality of interest groups prevails together with limited public resources and a large agenda of community needs to be faced and overcome in order to promote change. Urban mobility is a typically complex issue in urban environments that requires demands attention and resources from public administrators because it has implications for many aspects of the everyday life of a society, such as the economy, health, and urban planning. 


\subsection{Strategies in Governmental Organizations}

Strategies are essential to organizations, especially in today's complex and dynamic environment, coping with unforeseen events. It is virtually impossible to conceive of an organization that faces this reality without any "artefacts of strategy" (Carter et al, p. 574, 2010)

Organizations need strategies to set the direction they will take in the future. More than ever, due to the turbulent environment, strategies are important to deal with one of the watchwords of this era, change (Whipp, 2006).

To deal with such complex environment, governmental agencies develop particular strategies to coordinate their efforts and resources as they seek to transform the intentions represented by public policies into actions (Crozier, 1987; Bovaird, 2008). These strategies constitute a mechanism for administrators to satisfy community expectations and needs. To accomplish their goals, government agencies have to adopt managerial approaches including performative strategies (Carter et al, 2010; Kornberger \& Clegg, 2011) that are more feasible in the context of public organizations.

The challenge, in this case, is the design of a process to cope with a diversity of interest groups and stakeholders, availability of resources (Pettigrew, 1977), creativity and innovation that result in the improvement of services and, therefore, the public good.

In governmental organizations, the mission generally is not represented in financial terms, as in corporations, but rather in more substantive terms. Thus, to fulfill their mission public bureaucracies need strategies, and strategies are essentially materialized through social practices. This concept includes non-routines, initiatives, conversations, negotiations, language, emotions, hunches, and feelings developed and shared by individuals to cope with the environment and achieve a desired future (Whipp, 2006).

To remain purposeful and to achieve not only sustainability but also legitimacy public entities need to develop strategies to respond to the demands and expectations of their stakeholders (Moore, 2000). Therefore, the capacity of public agencies to be responsive to community needs is directly related to the managerial skills of their leaders to read the environment and implement the most feasible and appropriate strategies to achieve organizational goals.

Strategy is usually represented by a diversity of facets, such as processes, thinking, decisions, actions, language and interpretations. Usually, strategy is explained as a rational process that produces plans and at other times is seen as symbol of professional management. In truth, it is a mix of analysis, art, creativity, and practices by managers in addition to political maneuvers and psychological interplay among individuals involving hunches, feelings and negotiations (Mintzberg, 1994, 2009).

Strategic practices are better identified by spontaneous and emergent initiatives taken informally in different echelons of organizations rather than rational actions by managers aligned with goals rationally planned at the headquarters of an organization. In any event, all these strategies in organizations are essentially practiced as a result of interactions between macro intentions and micro actions (Meyer et al, 2018).

However, sometimes strategy is understood and explained retrospectively through sensemaking (Weick, 1979). This means only after the fact, when a particular set of practices or efforts can be considered "strategic" for an organization but not a priori. The key, in this case, is the extent to which relevant outcomes derived from such strategies enhance organizational performance, provide an advantage in the competitive market or meet the needs and expectations of stakeholders, strengthening or improving organizational image and legitimacy.

To implement strategies effectively in pluralistic contexts (Jarzabkowski \& Fenton, 2016), such as public bureaucracies, leadership and political capital (Banfield, 1961; Kjaer, 2013) are critical factors for managers. Therefore, they need to share motivation, commitment, and enthusiasm 
with the group to make individuals commit to their vision, power, and knowledge, which are pivotal to successful leadership. In this respect, Mantere (2005) coined the term "strategic champions" to refer to individuals who assume the responsibility for making and managing strategic decisions and actions in a particular organizational context.

Organizations are political arenas, and this is particularly the case of governmental agencies. In this context, power and politics play a significant role in any strategic effort (Flyvbjerg, 1998; Clegg et al, 2011). As a result, strategies emerge mainly as a result of negotiations, bargaining and psychological interplay, in addition to economic, financial and budgetary factors.

These elements reflect the diversity involved in the change process. In public administration, expectations are concentrated on the quality of services provided and improvement in the standard of living in a specific locality.

\subsection{Cities as Complex Systems}

Cities are complex systems. They are open systems, built by different parties with distinct and competing interests. They can be described as both a large-scale social network (Hidalgo, 2011) and a complex adaptive system (Stacey, 1996, 2011). These characteristics lead public administration to constantly adapt and respond to the dynamic environment (Bankes, 2011).

Urban centers throughout the world are expanding significantly due to their growing population. Nowadays, $55 \%$ of the people on our planet live in urban areas and by 2050 this number will have increased to $68 \%$ (United Nations, 2019).

Cities are increasingly becoming large and complex networks in which social, organizational, physical, and environmental systems are somehow interacting (Bettencourt, 2014). As urban centers develop, there is an increase in the number of people, buildings, houses, parks, streets, cars, buses, trains, and trees. Together, these constitute a densely built space. In this type of setting, our cities can be viewed as a complex system to be understood and managed.

Comprehending a complex system and its behavior requires a clear understanding of these elements and how they are interconnected. Thus, it is not only possible but necessary to examine our postmodern society and its organizations through the lens of complex theory and, particularly, as a complex system (Allen et al, 2011).

Complex systems also display a degree of complexity that goes beyond the limits of human cognition. Their internal dynamics, self-organizing and nonlinearity feedback features, together with an intense interaction and exchange of energy and information among heterogeneous agents, make their management processes a challenge and their outcomes unpredictable (Gell-mann, 1994, 1995; Cilliers, 1998; McDaniel, 2007).

In addition to their unique and intrinsic features, complex systems develop a constant interaction of a dynamic and ever-changing external environment both influencing and being influenced by external forces. Energy and information are exchanged with the context, but the forces of the environment remain unpredictable and unforeseen, which means that complex systems are always faced with uncertainty. For all these reasons complex systems are far more difficult to manage than other kinds of organized systems (Cilliers, 1998; Richardson, 2011; Sargut \& McGrath, 2011), requiring managerial pluralism (Richardson, 2005).

Increasing concerns have been raised over the quality of life in urban areas. A number of problems related to the topic include quality of public services, pollution, safety, social exclusion, discrimination and fear. It is a challenge for those in charge of public administration to manage such a variety of issues. As far as public service is concerned, governments have been widely criticized due to the low quality and inefficiency of public transport. This critical sector of today's society can 
be identified as a complex adaptive system (Stacey, 1996, 2011; McDaniel \& Driebe, 2005; McDaniel, 2007; Allen et al, 2011).

\subsection{Public Policy and Urban Mobility}

Cities, examined as complex system, require public policies to deal with their dynamics, which are derived from the connections and interactions of their elements. Urban mobility as a focus of public administration's attention will require strategic actions and adaptive mechanisms to cope with its challenges.

The concept of urban mobility has also evolved in the last 20 years. Initially, it focused on roads and infrastructure for cars. However, it now focuses on restricting cars, promoting sustainable practices (Ribeiro et al, 2019), and increasing infrastructure for public transport and non-motorized forms of transportation (Cervero et al, 2017).

As the concept of urban mobility evolved, so did its management and complexity. Its management has become a vital component of any city and a complex challenge, as it combines conflicting interests, symbolic values, and has a high economic and social impact, characterizing a typical complex socio-technical system. Urban mobility also influences the physical shape, as well as the economic and social development, of the city, and is the result of the interaction of several elements (Frazier \& Kockelman, 2004; Ettema, 2014; Cascetta et al, 2015).

The expansion, in the last 50 years of the urbanization process throughout the world, has increased the importance of mobility, particularly in major urban centers. According to Acharya (2005), trends such as rapid urbanization and growing economic prosperity have resulted in a higher rate of motorization in developing countries. Consequently, mobility has now become, more than ever, a critical element in determining the quality of people's lives. As a result, in poor countries, the lack of public resources has led cities to stimulate individual forms of transportation rather than public transport (Acharya, 2005; Gilbert, 2008).

Despite the complexity of the challenges, many cities have been successful in tackling the problems of urban mobility. In developed countries, large and continuous investments in transport infrastructure have improved roads and public transportation. However, in developing countries, the lack of resources available for large investments make creativity a necessary ingredient when it comes to solving major problems like urban mobility (Montgomery, 2013).

On this matter, Vuchic (1999) emphasizes the central role of public policies in achieving changes in patterns of urban mobility. Public policies must be used to induce and lead changes in urban mobility so that higher standards of services for users can be attained.

One of the major challenges in urban mobility in big cities is the creation of mass transportation systems that can be used by large numbers of people. Many countries have already proved that mass transport creates important benefits for most of the population in social, economic, environmental, and urban terms (Montezuma, 1995).

In the emerging world, it is necessary to develop policies and strategies that improve urban mobility without spending large sums of capital. Many experiments, like subways and trams, have been attempted, but one has proved to be an efficient solution, the Bus Rapid Transit (BRT). To Gilbert (2008), the success of BRT systems can be attributed to the fact that they are far superior to traditional bus systems, and much cheaper than subways.

The BRT system was responsible for the re-emergence of buses as a high-level public service provider (Rodriguez \& Targa, 2004). Prior to the BRT system, the common belief was that buses were a poor-quality public transport option, mainly because they were slow, uncomfortable, and never on time (Rodriguez \& Targa, 2004). 
Research in the field of transport economy, conducted internationally, has proved that BRT systems are superior in terms of high capacity of usage than other options, such as trains and subways (Hensher, 2007; Daganzo, 2010). Governments use irrational factors, such as aesthetic issues and historical tradition, other than efficiency, to justify their options for other forms of public transport rather than BRT systems (Hensher, 2007; Daganzo, 2010).

Another important issue is the fact that BRT solutions also allow public planners greater flexibility than rail-based options since they can be adapted more easily to accommodate changes in demand. This is especially important when there is a need to negotiate with politicians and other stakeholders (Ardila-Gomez, 2004).

After studying bus system implementations in 11 different cities in Latin America and Asia, Hidalgo \& Grafiteaux (2008) stressed that political leadership and clear vision in leading the process were key factors for the success of any endeavor in this area because they lead to a time reduction in the planning and implementation efforts of the public transportation solution.

Despite all the strategies and managerial solutions available, selecting the most appropriate approach, considering the timeframe of its implementation, is one of the most important decisions (Acharya, 2005).

\section{METHOD}

This is an in-depth case study of a qualitative nature (Yin, 2003; Stake, 1995). It is based on open question interviews, direct observation, and document analysis. The collected data were analyzed using triangulation (Eisenhardt, 1989) and submitted to content analysis.

One of the advantages of qualitative case studies is that the methodology allows the researcher to combine different research techniques and triangulate the data, thereby enriching the analysis (Yin, 2003; Creswell, 2013). Triangulation is also important as it increases the validity and credibility of the data (Eisenhardt, 1989; Yin, 2003).

The case was selected due to the fact that it represents a large-scale transformation in the public transportation model, understood as a complex system, moving from a chaotic reality to an internationally recognized system. The case of Bogotá has also been appraised by experts in the field worldwide.

\subsection{Interviews}

The researchers collected extensive empirical data that included a total of 10 in-depth interviews, with eight participants in the implementation of Bogotás innovative urban mobility system, including the city mayor who was responsible for the initial implementation and transformation process during his first term plus a selected group of technicians and public officers who participated in the process. A Brazilian urban mobility specialist who studied Bogotá's system was also interviewed. The objective of the interviews was to comprehend the change process, and particularly the public policies and strategies that were enacted during the transformation in Bogotá's public transportation system. The interviews were conducted by the researchers, both in Brazil and Colombia, in 2014 and 2015. The interviews were transcribed in a field diary. The interviewees were selected by convenience and due to their direct involvement in the change process. A list of the 10 interviewees with their positions within the organization is presented in Table 1. 
Box 1: List of Interviewees

\begin{tabular}{|c|c|c|}
\hline Interviewee & Position & Number of interviews \\
\hline 1 & Former Mayor of Bogotá & 2 \\
\hline 2 & First President of Transmilenio & 1 \\
\hline 3 & Senior Engineer at Transmilenio & 1 \\
\hline 4 & Engineer 1 at Transmilenio & 1 \\
\hline 5 & Engineer 2 at Transmilenio & 1 \\
\hline 6 & $\begin{array}{r}\text { Urban Mobility consultant who worked in the model- } \\
\text { ling of Bogota's transportation system }\end{array}$ \\
\hline 7 & Engineer at Bogotá's Urban Mobility Department & 1 \\
\hline 8 & Urban Mobility Engineering Specialist & 2 \\
\hline
\end{tabular}

Source: Primary Data (2014)

\subsection{Observation}

The direct non-participant observation took place in Bogotá, with the guidance of Transmilenio managers, in November 2014. The researchers were also taken by two Transmilenio engineers to visit and experience the new the public system and better understand the magnitude of the change process that Bogota's public transport system underwent. The observations were also registered in a field diary. Direct non-participant observation enabled the researchers to obtain descriptive data and facts pertaining to the real life of the organization (Jaccoud; Meyer, 2008).

\subsection{Secondary Data}

In addition to the interviews and direct observation, three other important sources of information were used to obtain data: (a) internal city administration documents; (b) research in the field conducted by academics; and (c) documents available on official websites. Access to all these sources was facilitated as the authors had the opportunity to visit the Transmilenio headquarters and the City Hall's Urban Mobility Department, in Bogotá, Colombia, in November 2014. The documents used in the study were mainly reports and presentations prepared by the city administration's urban mobility specialists. More recent data were added to the analysis, updating the information on the system's operation.

\subsection{Case Description}

From the 1960s to the late 1990s, public transportation was run by private businessmen in an anarchic form, which was also inefficient, expensive, and not sustainable. This reality led to a crisis that emerged in the late 1990s (Transmilenio, 2018).

To address this difficult situation, Mayor Enrique Peñalosa (1998-2000) included in his government plan a priority project called "Por la Bogotá que queremos" which determined the construction of a special infrastructure intended to create a massive public transportation system. This project developed exclusive lanes for BRTs, bridges, bus stations, cycle paths and squares with special access for people. The aim of this transformation was to improve the system for its users (Transmilenio, 2018).

The system received a second round of investments during the term of the mayor who succeed former mayor Peñalosa for the 2001-2003 term. Nowadays, the system has $112.9 \mathrm{~km}$ of main operation lanes, 134 bus stations, 9 bus garages, and 16 bicycle parking areas with a total of 3578 spots (Transmilenio, 2018). 
The change in Bogotá's public transportation system signaled a significant modification in the system, with the outcomes recognized not only locally and nationally, but also internationally. One of the reasons that make the study Bogotá's case so unique is the fact that the city underwent an extensive transformation process, from a city considered as one of the most chaotic urban mobility and transport systems in the world to an efficient and internationally recognized model based on a Bus Rapid Transit (BRT) application (Cervero et al, 2017). Inspired by the example of Curitiba, a city in the south of Brazil, Bogotá succeeded in increasing the use of public transport and improving the quality of the service provided.

\subsection{Analysis}

Bogotá's public transport system was badly organized and in a state of disarray prior to 1998. The system at that time was described by one of the key participants in the transformation process of the city`s urban mobility system from scratch, as follows: "In 1998, there were 22,000 public buses in Bogotá, which had been in use for an average of 16 years. Many of them were owned by their drivers, who made up their own rules of service. The system was poorly managed, and the quality of its services was very low" (Interviewee 2). Furthermore, according to the same source, the system was dominated at that time by a cartel of bus owners and transportation companies that were known to be corrupt.

Bus owners in Bogota developed fierce competition, which resulted in the "Guerra del centavo" or "penny war" (Interviewee 2). This led to a decline in the quality of service, as drivers would do anything to pick up as many passengers as they could, disregarding any rules or security procedures (Ardila-Gomez, 2004).

The description of the old public transportation system of Bogota, given by all the interviewees, was the worst possible. The interviewees were unanimous in highlighting that the lack of coordination, rules, standards of public service and the predatory competition between bus drivers created a chaotic system, in which quality was the last attribute to be considered. The need for change was evident, but promoting it was difficult due to the complexity involved (Cilliers, 1998; Frazier \& Kockelman, 2004; Bettencourt, 2014; Ettema, 2014; Cascetta et al, 2015).

This transformation process in Bogotá's urban mobility was only possible due to a strategic change led by the city administration during the three-year term of Mayor Enrique Peñalosa (19982000). He envisioned that a radical transformation of the situation was essential to improve the living conditions of the population (Gilbert, 2008). Peñalosa claimed that "Mayors win an election and it is only when they take office that they find out what they have to do. I already knew what I had to do before I got there" (Interview excerpt).

In 1996, the municipality held a referendum in which traffic congestion was declared to be the worst problem facing the city in the mid-1990s (Montezuma, 2005). Thus, improving the public transport system was a strong popular demand and resolving the problem an important ingredient for improving the quality of life of the people of Bogota.

Without an enormous budget to invest in infrastructure, the mayor realized that he had to be creative. With this strategy in mind, he implemented an integrated public transport system based on Bus Rapid Transit (BRT) technology, inspired by the example set by the Brazilian city of Curitiba. In this respect, regarding urban mobility, the former mayor affirmed: "Bogotá is not an example of anything; what we have done is implement successful examples of public policies from other parts of the world, especially Curitiba" (Interview excerpt).

The city administration was convinced that BRT was the best suited public transport technology for the landscape and features of Bogotá. The fact that the city is one of the most densely 
populated in the world, with approximately 230 people/hectare (Rodriguez \& Targa, 2004), also contributed to the implementation of the BRT system, since users did not live far from the bus lanes.

The introduction of the BRT system meant an investment of around \$2.4 billion U.S. dollars, which represented one fourth of the estimated investment for a subway system for Bogota (Ardila-Gomez, 2004). Moreover, the cost of its implementation and management could be met by the city government (Interviewee 2 ).

Municipal governments, especially in emergent economies, where resources are limited and social demands are abundant, generally do not have sufficient resources to invest in large infrastructure projects. Under these conditions, it was necessary to explore creativity and benchmarking strategies to identify the best practices used by other cities and analyze the feasibility of implementing them elsewhere.

In order to implement the change process, a number of strategies were implemented by the local administration. The first strategy was concentrated on an in-depth study of the urban mobility situation and examining feasible alternatives for discussion. For this purpose, the municipality hired a Brazilian transport consulting firm that worked on the implementation of Curitiba's BRT system to participate in this phase. On this matter, an urban mobility consultant that works for this firm stated that "the mayor knew clearly what he wanted in terms of urban mobility and gave us a hard time to make sure we got there" (Interviewee 6).

After studying the situation and examining viable alternatives to face the problem, the city administration explored a second strategy with a focus on building an integrated public transport system based on the BRT concept, with exclusive lanes, bus stations and terminals. The BRT system would cover the most densely populated and busiest central areas of the Colombian capital and would be fed by an integrated system of smaller public buses, transporting people from all the other neighborhoods of Bogotá. An important lesson to be learned from Bogota's case is that planning matters (Cervero et al, 2017).

A third strategy implemented by the city administration concentrated on civil participation, without allowing political concessions to mischaracterize the technical solution. Mayor Peñalosa stimulated civil participation in politics, but also believed that there were "battles one has to fight" (Ardila-Gomez, 2004, p. 290). Thus, a technical solution to public transport was brought about by stimulating discussions of the project but without engaging in political negotiations that could jeopardize it (Ardila-Gomez, 2004, p. 290).

The BRT system was handled by a single public transportation company, called Transmilenio, managed by the local government. The company is responsible for planning and managing the operation of the BRT buses and terminals. The bus companies are responsible for the buses, the employees, and the ticketing. Thus, this public company innovated its business model by generating a joint management of the public transportation system with its private operators.

Transmilenio's joint management was certainly one of the most important strategies, the fourth, and a critical success factor behind Bogota's urban mobility revolution. This company "represented a change of paradigm that implied new contractual and institutional arrangements" (Ardila-Gomez, 2004, p. 292) and was responsible for the planning and concessioning of the public transportation system. This joint management forces the operators (bus companies) and local government to recognize each other's interests and jointly seek ways to accommodate one another on a daily basis, reducing potential conflicts (Interviewee 4).

The public transportation operation was conceded by Transmilenio to private bus companies. However, Transmilenio maintains control over the system's planning and management aspects, and this is done in cooperation with the operators through joint committees (Ardila-Gomez, 2004). 
However, it was necessary to make the system attractive and, to do so, several features were necessary: (a) comfortable and clean bus stations; (b) fast and comfortable buses; (c) buses that ran on time; and (d) a "sexy" name (Interviewee 1). Regarding these features, a fast bus service is the most important factor when it comes to the approval rates of users (Interviewee 1).

The BRT system is attractive and efficient, with comfortable buses that arrive in well-organized bus terminals and use exclusive lanes, which enables users to reach their destinations much faster than before. Not only are the buses efficient, but they also look good (Direct Observation).

The introduction of the BRT system disarticulated the old and inefficient public transport of Bogotá. This obviously brought very strong interests into conflict with City Hall. The conflict had such serious ramifications that bus owners and drivers decided to go on strike just before the inauguration of the new system. The strike paralyzed the Colombian capital for several days, putting considerable pressure on the mayor. However, Mayor Peñalosa knew he had to confront strong interests to change the status quo (Ardila-Gomez, 2004).

A telephone call from the President of Colombia, Andres Pastrana, was received by Mayor Peñalosa, asking him to ease back on the radical change process in the public transport system to bring Bogota's major transportation's strike to a halt. Disregarding this strong political pressure, the mayor decided to continue the change process because he believed in the importance of the new mobility system to the city (Interviewee 1 ). This is a clear example of how complex (Cilliers, 1998) the change process was for the city administration, not only politically, but also in terms of leadership, power, process, and technical issues of urban management (Flyvbjerg, 1998; Frazier \& Kockelman, 2004; Clegg et al., 2011; Bettencourt, 2014; Ettema, 2014; Cascetta et al, 2015).

After the strike and the introduction of the BRT, it took a while for the population to understand and approve the changes in the city's mobility system. Peñalosa faced strong opposition in his first two years in office and halfway through his term he had an approval rating of only $26 \%$ (Ardila-Gomez, 2004, p. 290). Later, the system was approved by its users and recognized as a great improvement over the previous one. Users enjoyed better quality vehicles, terminals and bus stations, and the system was more reliable and took people to their destinations faster. By the end of his term, in 2000, Peñalosa's approval rating had increased to $53 \%$ and $40 \%$ of the respondents considered his administration "excellent" (Ardila-Gomez, 2004, p. 290).

Another relevant strategy, the fifth one, was the introduction of non-motorized forms of transport into the urban mobility system by the city administration. This was done especially by investing in sidewalks, bicycle lanes and cycle paths, connecting them to the BRT stations and creating safe bicycle parking areas in the bus stations. This enabled more people to access the BRT system on their own without using feeder buses - called alimentadores in Spanish (Interviewee 7).

The upgrade of Bogota's sidewalks, bicycle lanes and cycle paths was achieved by reducing parking spots and space for cars in the streets. This, initially, also generated complaints and protests from car users and small businessmen. However, after a time, it also came to be accepted and the population was proud of the new public spaces for walking, socializing, and riding bicycles (Interviewee 7). Less parking space also led more people to use public transport.

Mayor Peñalosa intended to construct 350 kilometers of cycle paths. However, he was only able to build approximately 270 kilometers by January 2003 (Montezuma, 2005). This number still made Bogota's network of bicycle paths the largest in Latin America and the developing world (Montezuma, 2005).

This public policy was so well received by the public that the mayors who succeeded him continued to increase the BRT system and expand the cycle paths to different parts of the city. From that point on, the BRT came to cover approximately $38 \%$ of the city, compared with the $25 \%$ it covered before, when first introduced (Interviewee 1). 
Another key benefit of the change process was the fact that Bogotá expanded to 376 kilometers of cycle paths and lanes and there are plans to expand the system by adding another 250 kilometers (Interviewee 7). There is also a specific set of policies and investments intended to make improvements and educate the population regarding bicycle use (Interviewee 7).

When Mayor Peñalosa left office, there were around 200 kilometers of bicycle lanes and paths in Bogotá (Interviewee 2), which can be considered a real improvement in the quality of life and the humanization of the city. All this investment in non-motorized mobility led around $4 \%$ of the population that commute in Bogota to use bicycles (Interviewee 7). This is a significant percentage for a Latin American city.

The drive for non-motorized forms of transport also encouraged more people to socialize on the sidewalk and practice exercises. All these positive results represent an important side effect of this well implemented public policy and an important change in behavior.

Bogota's BRT produced many positive externalities and among them the decrease in air pollution, carbon emission and automobile accidents deserve to be highlighted. Furthermore, they improved the city's walkability (Lemoine et al, 2016)

To improve the urban mobility of Bogota there was a need to stimulate more people to use the new public transport system. Therefore, City Hall introduced a sixth strategy, called "Pico $y$ Placa" or "Rush Hour and License Plate" which prohibited certain license plates from circulating on specific days and times. This strategy had immediate results, reducing traffic jams and travel times, and leading car users to use other transport modes (Hidalgo, 2014).

The BRT also proved to be a system of high-capacity use and low implementation costs, especially when compared to subways, cable cars or light rail (Gilbert, 2008). The BRT system also has a significant advantage over other models, which is greater flexibility to adapt to changes in demands and routes. The BRT system also has a third strength, which lies in its high capacity for passengers.

Transmilenio began operating in late 2000, and by April 2002 it was already transporting 650,000 passengers per day in 38-kilometer exclusive bus lanes, with 62 bus stations and 470 articulated buses (Sandoval \& Hidalgo, 2004). Interviewee 3 estimates that around two million people use Transmilenio buses every day.

The model of Bogotá's BRT was very well developed and evolved in such a way that it actually became more efficient than that of Curitiba, by which it was inspired (Interviewee 3). Bogotá has become a benchmark for urban mobility management in emergent countries. The case of Bogota proved that BRT is a possible solution for urban mobility in large cities (Ardila-Gomez, 2004). It is now the BRT implementation with the highest number of passengers in the world. By late 2002, it was carrying more than 35,000 passengers per hour per direction, more than most subways in the world (Hidalgo, 2003).

Nowadays, the system covers more than 112 kilometers of dedicated lanes, has 134 bus stations, and moves almost 2 million passengers every day, accounting for $30 \%$ of the city's total demand for public transportation (Transmilenio, 2017). Transmilenio continues to innovate and recently, in July 2019, announced the purchase of 600 electric buses, constituting the largest fleet of electric buses in Latin America (Transmilenio, 2019).

\section{DISCUSSION}

The case revealed that the capital of Colombia is a clear example of a successful change process in a complex adaptive system (Gell-Mann, 1994, 1995; Stacey, 1996, 2011). This fact was only made possible due to a combination of factors: a leadership with political capital (Banfield, 
1961; Kjaer, 2013) determined to implement a clear public policy that combined with a set of incremental strategies (Carter et al, 2010) and investments.

Three main points can be identified in the municipal government of Bogota's change process in the transport system, with significant outcomes. First, there was a change in the paradigm that a bus service is inefficient, uncomfortable, and used exclusively by poor people. Transmilenio buses and stations are efficient, comfortable, and used by people from all walks of life. Second, the significant change implemented by the city administration made Bogota more sustainable (Ribeiro et al, 2019), livable, healthier and less car dependent as the investments in public infrastructure provided more public spaces for social interactions and allowed more people to use public transportation, walk and cycle. Third, the city was creative by using an efficient solution to public transportation that was compatible with its financial conditions.

The evolution promoted by Bogota surpassed its model of inspiration, Curitiba, for two basic reasons. First, because it was able to integrate its central BRT system with more parts of the city and surrounding area by using an extensive network of feeder buses (alimentadores). Second, it has a higher capacity for carrying passengers, approximately two million per day (Transmilenio, 2017).

Nowadays, there is a great need for new investments in the system, as it is clearly overloaded during peak time. To preserve its reputation and the quality of service, it will be necessary to expand the BRT system to other parts of the Colombian capital and enlarge certain terminals. One of the main challenges of Bogota's urban mobility, as pointed out by Montezuma (2005), is to transform it into an integrated multimodal system, with trains, non-motorized transport, a subway, buses, public spaces, and automobiles.

Promoting change in an urban mobility system of a large city, such as Bogota, is an enormous challenge. Countless problems emerged due to the slow internal bureaucracy, political pressures, limited resources, and technical knowledge. All of this required strong leadership, political negotiations, key decisions, and appropriate strategies, characterized by creativity in the concept and swift implementation. These elements required unique managerial skills in public administration, which were pivotal to the feasibility of the change process in a such a relatively short period of time. This is a remarkable achievement, considering the characteristics of public administration.

The experience of Bogotá offers an example of reorganizing public transport that Vuchic (1999) qualifies as the central role of public policies in city administration. The success of the implemented strategies were also adapted to the geographical, economic, and social characteristics (Bankes, 2011) of the Colombian capital, which can also be highlighted as one of the success factors (Acharya, 2005).

Bogotá's case also illustrates how a complex problem (Cilliers, 1998) can be mitigated through the implementation of strategies (Bovaird, 2008; Carter et al, 2010) combined with a technical component and a top-down approach. The social participation (Fung, 2006) for discussing the strategies used by the local administration was not among the main characteristics of the process. However, an initial lack of legitimacy was certainly compensated for by a faster implementation time and an efficient urban mobility system. This was made possible due to the strong commitment of Mayor Peñalosa to the project, his leadership, political capital (Banfield, 1961; Kjaer, 2013), and will to make it happen (Hidalgo \& Grafiteaux, 2008). The mayor's effort can be clearly classified as a strategic champion (Mantere, 2005).

It is worth noting that the continuous efforts made by the city administration of Bogotá have ensured that it remains among the most successful cases of urban mobility in Latin America by constantly innovating and providing the population with better quality of life. 


\section{CONCLUDING REMARKS}

The revolution promoted in Bogota, transforming a chaotic public transport system and setting an example for the rest of the world, is a notable effort. It can be classified as a set of a performative strategies (Carter et al, 2010; Kornberger \& Clegg, 2011) based on a technical approach, inspired by a Brazilian creation, but complemented by emergent strategies. The six strategies identified were crucial to the success of the urban mobility change implemented in the city.

The case provides public administrators with many insights, which are used to manage organizations that operate complex systems (Cilliers, 1998; Bovaird, 2008) and pluralistic contexts (Jarzabkowski \& Fenton, 2016), such as urban mobility (Frazier \& Kockelman, 2004). The initial findings reveal four important aspects regarding the change in public mobility in Bogotá.

First, the city of Bogotá had the courage to tackle a complex political problem, which was the old transport system. The case reveals how the local government used different strategies to handle such a complex situation, which is uncommon among elected representatives. Second, the urban mobility system used in Bogotá combined two important factors for developing countries: lower cost of implementation and large capacity for passengers. Third, by integrating non-motorized forms of transport, the city was able to reduce the cost of operating the public transport system. Fourth, the transportation system was able to integrate concepts that are important to any city nowadays: quality of life, sustainability, and humanization.

It is relevant to highlight the "engineering" involved in creating the urban mobility company Transmilenio so that the system could be jointly managed by the government and bus companies. This type of arrangement strengthens the ties between the public and private sector and their commitment to the achievement of two important objectives, namely quality of public services and profitability.

This transformation of public transportation in Bogota in such a short time was only made possible due to the presence of a strong and determined mayor (Hidalgo \& Grafiteaux, 2008), who empowered city planners. These city planners were also politically savvy to negotiate with local politicians and the community in order to accommodate their interests without jeopardizing the project.

This article contributes to the literature by discussing a unique case study of a municipality that successfully tackled an important issue by using a unique approach that was well suited to its characteristics. It is also a representative case of creative policies developed in an emergent country, in which local government mitigates a complex urban problem by implementing an efficient alternative. The successful implementation of such a complex transformation in municipal public administration is not commonplace (Gilbert, 2008), which highlights the relevance of this study.

Further research should observe how other cities around the world managed urban mobility issues. Researchers in the field could explore particular cases in which governments implemented new initiatives to respond to urban mobility challenges around the developing world. This type of study would enable the identification of cases in which common features and unique patterns of public policies, strategies and actions can be identified, thereby contributing to the expansion of knowledge in this field. Future research should also focus on studies related to urban mobility, clean fuels, public health and environmental protection, and initiatives for the humanization of urban centers. 


\section{REFERENCES}

Acharya, S. R. (2005) Motorization and Urban Mobility in Developing Countries Exploring Policy Options through Dynamic Simulation. Journal of the Eastern Asia Society for Transportation Studies, 6, p. $4113-4128$.

Allen, P., Maguire, S. \& McKelvey, B. (2011) The Sage Handbook of Complexity and Management. London: Sage Publications.

Anderson, P. \& Meyer, A. D. Complexity Theory and Process Organization Studies. In: Langley, A. \& Tsoukas, H. (2017) The Sage Handbook of Process Organization Studies. London: Sage Publications, p. 127-143.

Ardila-Gómez, A. (2004) Transit Planning in Curitiba and Bogotá: roles in interaction, risk, and change. Ph.D. Theses, Massachusetts Institute of Technology. Cambridge (MA). Available at: http://dspace.mit.edu/handle/1721.1/28791. Access in: March 3r, 2017.

Banfield, E. (1961) Political influence - a new theory of urban politics. The Free Press, New York.

Bankes, S. The Use of Complexity for Policy Exploration. In: Allen, P., Maguire, S. \& McKelvey, B. (2011) The Sage Handbook of Complexity and Management. London: Sage Publications, p. 570-589.

Barber, B. R. (2013) If mayors ruled the world: dysfunctional nations, rising cities. New Haven: Yale University Press.

Bettencourt, L. Cities are complex systems. In: Furtado, B.A., Sakowski, P. A. M. \& Tovolli, M. H. (eds). (2014) Modeling Complex Systems for Public Policy. Brasilia: IPEA, p. 241-263.

Bovaird, T. (2008) Emergent strategic management and planning mechanisms in complex adaptive systems. Public Management Review, 10 (3), p. 319-340.

Carter, C.; Clegg, S. \& Kornberger, M. (2010) Re-framing strategy: power, politics and accounting. Accounting, Auditing \& Accountability Journal, 23 (5), p. 573-594.

Cascetta, E., Pagliara, F. \& Papola, A. (2007) Governance of Urban Mobility: complex systems and integrated policies. Advances in Complex Systems, 10 (2), p. 339-354.

Cervero, R.; Guerra, E. \& Al, S. (2017) Beyond Mobility: planning cities for people and places. Washington: Island Press.

Cilliers, P. (1998) Complexity and Postmodernism: understanding complex systems. London: Routledge.

Clegg, S., Carter, C., Kornberger, M., \& Schweitzer, J. (2011) Strategy: theory and practice. London: Sage Publications.

Creswell, J. W. (2013) Qualitative Inquiry and Research Design: Choosing among five approaches. Los Angeles: Sage Publications.

Crozier, M. (1987) État Modeste, État Moderne: stratégie pour un autre chamgement. Paris: Éditions Fayard. 
Daganzo, C. F. (2010) Structure of competitive transit networks. Transportation Research Part B: Methodological, 44 (4), p. 434-446.

Dye, T. R. (2017) Understanding public policy. Boston: Pearson.

Eisenhardt, K. M. (1989) Building theories from case study research. Academy of Management Review, 14 (4), p. 532-550.

Ettema, D. Complexity Methods Applied to Transport Planning. In: Furtado, B.A.; Sakowski, P. A. M. \& Tovolli, M. H. (2014) Modeling Complex Systems for Public Policy. Brasilia: IPEA., p. 279-300.

Flyvbjerg, B. (1998) Rationality and Power: democracy in practice. Chicago: The University of Chicago Press.

Frazier, C.; Kockelman, K. (2004) Chaos Theory and Transportation systems: an instructive example. Transportation Research Record, 1897, Jan., p. 9-17.

Fung, A. (2006) Varieties of Participation in Complex Governance. Public Administration Review, Special Issue, Dec., p. 66-75.

Gell-mann, M. (1994) The Quark and the Jaguar: adventures in the simple and the complex. New York: Owl Books.

Gell-mann, M. (1995) What is complexity? Complexity, 1 (1).

Gilbert, A. (2008) Bus Rapid Transit: is TransMilenio a miracle cure? Transport Reviews, 28 (4), p. 439-467.

Hensher, D. A. (2007) Sustainable public transport systems: moving towards a value for money and network-based approach and away from blind commitment. Transport Policy, 14 (1), p. $98-$ 102.

Hildago, C. The Value in Between: organizations as adapting and evolving networks. In: Allen, P., Maguire, S. \& McKelvey, B. (2011) The Sage Handbook of Complexity and Management. London: Sage Publications, p. 557-569.

Hidalgo, D. (2003) Contribuciones de TransMilenio a los Sistemas de Transporte Masivo de Alta Capacidad en Buses BRT. Paper presented at The Conference Seminario Internacional de Movilidad Alternativa y Humana, Bogota, February 6-9, 2003. Fundación Ciudad Humana, Institute for Transport Development Policy and Alcaldia Mayor de Bogota.

Hidalgo, D. \& Grafiteaux, P. (2008) Bus Rapid Transit Systems in Latin America and Asia: Results and Difficulties in 11 Cities. Transportation Research Record Journal of the Transportation Research Board. 2072, p. 77-88.

Hidalgo, D. (2014) Urbanism Hall of Fame: Enrique Peñalosa leads Bogotá's inclusive urban transformation. Integrated Transport. The City Fix. Available in: http://thecityfix.com/ blog/urbanism-hall-of-fame-enrique-penalosa-bogota-inclusive-urban-sustainabletransformation-dario-hidalgo . Access in: March, 28 ${ }^{\text {th }}, 2017$.

Jaccoud, M. \& Meyer, R. A observação direta e a pesquisa qualitativa. In: Poupart, J., Deslauriers, J. P., Groulx, L. H., Lapierre, A., Mayer, R. \& Pires, A. R.. (2008) A pesquisa qualitativa: enfoques 
epistemológico e metodológicos. Petrópolis: Vozes, 2008.

Jarzabkowski, P. \& Fenton, E. (2016) Strategizing and organizing in pluralistic contexts. Long Range Planning, 39 (6), p. 631-648.

Kjaer, U. (2013) Local political leadership: the art of circulating political capital. Local Government Studies, 39 (2), p. 253-272.

Kornberger, M. \& Clegg, S. (2011) Strategy as Performative Practice: The Case of Sydney 2030. Strategy Organization, 9 (2), p. 136-162.

Lemoine, P.; Sarmiento, O. L.; Ortiz, J. D. P.; Meisel, J.; Montes, F.; Hildago, D.; Pratt, M.; Zambrano, J. M.; Cordovez, J. M. \& Zarama, R. (2016) Transmilenio, a Scalable Bus Rapid Transit System for Promoting Physical Activity. Journal of Urban Health, 93 (2), p. 3-17.

McDaniel, R., Jr. \& Driebe, D. J. (2005) Uncertainty and surprise in complex systems. Springer Verlag Heidelberg.

McDaniel, R. Jr. (2007) Managing Strategies for Complex Adaptive Systems. Performance Improvement Quarterly, 20 (2), p. 21-42.

Mantere, S. (2005) Strategic Practices as Enablers and Disablers of Championing Activity. Strategic Organization, 3 (2), p. 157-184.

Meyer, V. Jr., Pascuci, L. \& Meyer, B. (2018) Strategies in universities: tensions between macro intentions and micro actions. RAC, 22 (2), p. 163-177, 2018.

Mintzberg, H. (1994) The Fall and Rise of Strategic Planning. Harvard Business Review, Jan.-Feb., p. 107-114.

Mintzberg, H. (2009) Managing. San Francisco: Berret-Koehler.

Montezuma, R. (2005) The Transformation of Bogotá, Colombia, 1995-2000: investing in citizenship and urban mobility. Global Urban Development, 1 (1), p. 1-10.

Montgomery, C. (2013) Happy City: transforming our lives through urban design. New York: Farrar, Straus and Giroux.

Moore, M.H. (2000) Managing for Value: Organizational strategy in for-profit, nonprofit and governmental organizations. Nonprofit and Voluntary Sector Quarterly, 29 (1), p. 183-204.

Pettigrew, A. (1987) Strategy Formulation as a Political Process. International Studies of Management and Organization, 7 (2), p. 78-87.

Ribeiro, T. S. V., Cortese, T. T. P., Kniess, C. T., \& Conti, D. M. (2019) What is the role of indicators as a governance tool to help cities become more sustainable. Revista de Administração da UFSM, $12(3)$, p. 580-593.

Richardson, K.A. (2005) Managing Organizational Complexity: philosophy, theory and application. Information Age Publishing: Greenwich, Connecticut.

Richardson, K.A. Complexity and Management: A Pluralistic View. In: Allen, P.; Maguire, S.; McKelvey, B. (2011) The Sage Hanbook of Complexity and Management. London: Sage, 366-382. 
Rodriguez, D. A. \& Targa, F. (2004) Value of Accessibility to Bogota's Bus Rapid Transit System. Transport Reviews, 24 (5), p. 587-610.

Sandoval, E.E. \& Hidalgo, D. (2004) Transmilenio: a high capacity - low-cost bus rapid transit system developed for Bogota, Colombia. Conference Paper. Second International Conference on Urban Public Transportation Systems. Alexandria, USA.

Sargut, G. \& McGrath, R. G. (2011) Learning to live with Complexity. Harvard Business Review, September.

Stacey, R.D. (1996) Complexity and Creativity in Organizations: the challenge of complexity. San Francisco: Berret-Koehler.

Stacey, R.D. (2011) Strategic Management and Organizational Dynamics. London: Prentice-Hall.

Stake, R. E. (1995) The art of case study research. Thousand Oaks: Sage Publications.

Transmilenio. (2017) Historia. TransMilenio S.A. Available in: http://www.transmilenio.gov.co/ Publicaciones/la_entidad/nuestra_entidad/Historia. Access in: March, 26 ${ }^{\text {th }}, 2017$.

Transmilenio. (2018) Historia de TransMilenio. TransMilenio S.A. Available in: https://www. transmilenio.gov.co/publicaciones/146028/historia-de-transmilenio/. Access in: January, $15^{\text {th }}$, 2018.

Transmilenio. (2019) Bogotá tendrá la flota de buses eléctricos más grande de Latinoamérica. Available in: https://www.transmilenio.gov.co/publicaciones/151302/bogota-tendra-la-flotade-buses-electricos-mas-grande-de-latinoamerica/ . Access in: September, 19th, 2019.

United Nations, Department of Economic and Social Affairs, Population Division. (2019) World Urbanization Prospects: The 2018 Revision (ST/ESA/SER.A/420). New York: United Nations. Available at: https://population.un.org/wup/Publications/Files/WUP2018-Report.pdf. Access in March 25th, 2019

Vuchic, V. R. (1999) Transportation for Livable Cities. New Jersey: Center for Urban Policy Research.

Weick, K.E. (1979) The Social Psychology of Organizing. New York: Random House.

Whipp. R. Managing Strategic Change. In: Faulkner, D. \& Campbell, A. (2006) The Oxford Handbook of Strategy. Oxford: Oxford University Press, p. 729-758.

Yin, R. K. (2003) Case study research: design and methods. London: Sage. 


\section{AUTHORS}

\section{Bernardo Meyer}

Universidade Federal de Santa Catarina, Florianópolis, Santa Catarina, Brazil.

Holds a Doctorate degree in Administration by Universidade Federal do Paraná, a Masters degree in Business Administration at DePaul University (USA), and a bachelors degree in Administration at Universidade do Estado de Santa Catarina.

Profesor at the Administration Graduate Programa (PPGA) at Universidade Federal de Santa Catarina.

E-mail: bernardo.meyer@ufsc.br

ORCID: https://orcid.org/0000-0003-1915-8695

\section{Victor Meyer Junior}

Pontifícia Universidade Católica do Paraná (PUCPR). Curitiba, Paraná, Brazil,

Holds a Doctorate and a Masters degree in Higher Education Management at University of Houston (USA), and a bachelors degree in Economics at Universidade Federal de Santa Catarina.

Profesor at the Administration Graduate Program (PPGA) at Pontificia Universidade Católica do Parana (PUCPR). ORCID: https://orcid.org/0000-0002-3576-2342

E-mail: victormeyerjr@gmail.com

\section{Contribution of authors}

\begin{tabular}{|l|c|c|}
\hline \multicolumn{1}{|c|}{ Contribution } & Author $\mathbf{1}$ & Autor $\mathbf{2}$ \\
\hline 1. Definition of research problem & $\mathbf{V}$ & \\
\hline 2. Development of hypotheses or research questions (empirical studies) & $\mathbf{V}$ & $\mathbf{V}$ \\
\hline 3. Development of theoretical propositions (theoretical work) & $\mathbf{V}$ & $\mathbf{V}$ \\
\hline 4. Theoretical foundation / Literature review & $\mathbf{V}$ & $\mathbf{V}$ \\
\hline 5. Definition of methodological procedures & $\mathbf{V}$ & $\mathbf{V}$ \\
\hline 6. Data collection & $\mathbf{V}$ & \\
\hline 7. Statistical analysis & - & - \\
\hline 8. Analysis and interpretation of data & $\mathbf{V}$ & $\mathbf{V}$ \\
\hline 9. Critical revision of the manuscript & $\mathbf{V}$ & $\mathbf{V}$ \\
\hline 10. Manuscript writing & $\mathbf{V}$ & $\mathbf{V}$ \\
\hline 11. Other (please specify) & - & - \\
\hline
\end{tabular}

\section{Conflict of Interest}

The authors have stated that there is no conflict of interest.

\section{Copyrights}

ReA/UFSM owns the copyright to this content.

\section{Plagiarism Check}

The ReA/UFSM maintains the practice of submitting all documents approved for publication to the plagiarism check, using specific tools, e.g.: CopySpider. 